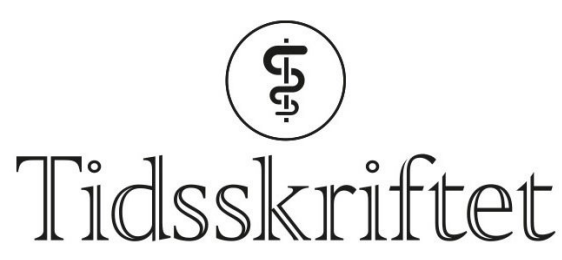

DEN NORSKE LEGEFORENING

\title{
Rettelse: Arbeidsrelatert håndeksem
}

RETTELSE

MARI SVEEN KVAM

JOSE HERNÁN ALFONSO

TERESA LøVOLD BERENTS

BRITT GRETHE RANDEM

EVA STYLIANOU

Tidsskr Nor Legeforen 2019; 139: 262-5.

I Tidsskriftet nr.3/2019 skal det sist i artikkelen stå: Publikasjonen har benyttet data fra Norsk pasientregister (NPR). Forfatterne er eneansvarlig for tolkning og presentasjon av de utleverte data. Registerforvalter for NPR har ikke ansvar for analyser eller tolkninger basert på de utleverte data.

Vi beklager feilen, den er rettet på nett.

Publisert: 8. februar 2019. Tidsskr Nor Legeforen. DOI: 10.4045/tidsskr.19.0125

(C) Tidsskrift for Den norske legeforening 2020. Lastet ned fra tidsskriftet.no 